\title{
Community Participation in Tourism Management in Samosir Regency, North Sumatera Province
}

\author{
Tjut Syahriani \\ Departement of Antropology, Faculty of Social and Political Sciences. \\ University of North Sumatera, Medan, Indonesia
}

\begin{abstract}
This study, entitled "Community Participation in Tourism Management in Samosir Regency, North Sumatera Province" is the result of the research conducted in three districts, namely Simanindo, Panguruan and Onan Rungu. This study is aimed to seek the reasons of the community who are not willing to be in charge in managing tourism in the area. Furthermore, this study is also aimed to explore the efforts conducted by the local government to manage and maintain through social/community enforcement. The next aim of this study is to find out the obstacles faced by the local government in managing and maintaining the social enforcement. This study follows qualitative research method in which data were collected through observation, deep interview and focus group discussion with the selected informants. The result of this study shows that the participation of the community in tourism management is still low. Local government has started managing and maintaining some tourism assets, namely, historical assets, such as : the grave of King Sidabutar, Hutabolon museum, and Chair (made of stone) of Persidanagan Sialogan. However, natural tourism has not been managed yet as expected. Some obstacles faced by the local government firstly is cultural obstacle, in which the assets are regarded/ believed as the ancestor's heritage which belong to the local people. The second obstacle is that of the local belief. It is forbidden by taboo to get access to those assets. It can be concluded that first, the community participation in tourism management is still low. Secondly, the efforts conducted by the local government have not been optimal yet. The obstacles faced by the local government are cultural obstacles and local wisdom.
\end{abstract}

Keywords: Community participation, management, maintain, tourism.

\section{INTRODUCTION}

Many countries in the world that rely on the addition of foreign exchange from tourism sector, thus the countries concerned will manage their tourism so well. This was done to invite tourist to visit there. One of the best way to manage tourism is to involve local communities, in addition to their economic benefits, they will always feel that it belong to them and must be continually maintained and do not ruin it.

Indonesia is a rich country in potential tourism which are spread across the province, from Sabang to Merauke. This time the islands Java and Bali became an importan tourism destination for Indonesia. One of the province that has great tourism assets are the province of North Sumatera..Lake Toba became an icon and travel ,in the past become a famous tourist spot both local and foreign.

Tourism potential is equally important in the province of North Sumatera are Samosir regency or better know as the Island of Samosir. Samosir Island is located adjacent to an area of Toba, and expantion of district TOBASA (Toba Samosir), so that every tourist who comes to the lake Toba will take the time to visit Samosir. But unfortunately there are still a lot of assets tourism on the Island of Samosir is still hidden and not yet come to the surface, in other words assets Samosir island tourism has not been managed well by the government especially local government.

The amount of assets tourism in an area does not have any meaning both economic and socio cultural, what if there is no goodwill from the 
government and the community to maintain and preserve it. Recognizing the importance of an asset tourism, the government of Indonesia through the law no 11 of 2010 on the cultural heritage, determined that the cultural heritage in the form of objects, structures and regions need to be manage by the government and local government to improve community participation to protect and exploit it.

Community involvement in the management tourism is important, according to Adimiharja (1999), community empowerment as a process that is not only just develop the economic potential of people who are powerless, but should also be able to enhance the dignity and the dignity, self - esteem and dignity of the people and maintaining order local cultural values.

The results of the study conducted by Syahriani (2014 ), which was funded DIKTI shows that there are two types of tourism in the island of Samosir is the historical and natural attractions spread over 9 district. These district are, Simanindo, Siajur Mulamula, Onan Runggu, Palpi, SitioTio, Panguruan Harian and Ronggurni Huta. Results of the study also shows that the management of tourism in several districts were not as expected and community involvement is still low.

From the description that has been described above, this study raises some questions as follow :

Why local people are less involved in the management of tourism in Samosir?

What obstacles facing local governments in the management of tourism on the island of Samosir?

What efforts made by the government in the management of tourism based on community empowerment?

\section{RESEARCH METHODS}

This study used a qualitative research method using an ethnographic approach. The study was conducted in three sub-districts in Samosir, namely; Simanindo districts, Pangururan and Onan Runggu. The three districts chosen with consideration that in these districts have encountered many tourist attractions, either already managed or not.

There are 2 data collected are, primary data and secondary data. Primary data can be directly from the field research using techniquest of observation and in-dept interviews using interview guide. Informants in this study is that some of the local communities, indigenous dean, and government officials in this case the clerk at the department of tourism Samosir regency. Secondary data were obtained from the records department of tourism Samosir regency, reading books, journals related to this research. In addition it also conducted FGD (Focus Group Discussion ) to determine the extent to which the community is involved performance management of tourism.

\section{Literature Review}

In essence tourism good governance is the coordination and synchronization of programs accros multiple stakeholders and active participation synergistic ( integrated and mutually reinforcing ) between the government and private / tourism industry and the local communities involved ( Sunaryo,2002 : 77 ). There are some cases that is contained in a book called "Tourism Passport Development " ,countries such as Cyprus, Malta and Greece, they manage tourism seriously by empowering local communities, so as to increase their income. Indeed socio-cultural changes in the local community as a livelihood from forming into entrepreneurial workers.( Emanuel,1979: 40)

One of the concepts of community participation is the empowerment of communities. Community development in the field of tourism is very important because the target to be achieved not only the economic value but also the added value that is beyond economic. (socio - cultural). Moelyarto Tjokrowinoto (in Mardikato and Soebianto, 2012 ) stated that the characteristics of development that is based on people are as follows :

The initiative and the process of decision maker to meet the needs of community, step by step should be put on the community itself.

Its main focus is to improve people's ability to manage and mobilize resources at their disposal to meet their needs.

This approach tolerate local variations due to its versatility and can adapt to local conditions.

In the performance of the construction, this approach emphasizes the social learning process in which there are collaborative interaction between the bureaucracy and the community, from planning 
to evaluation of projects by basing ourselves on mutual learning.

The process of the formation of networks between the bureaucracy and non government organizations entities traditionally independent organization is an integral portion of this approach.

According to Rahman (1982) participation is an active process, meaning that the person or group concerned to take initiatives and ensure the authority to do something. Uphoof and Conen (in Syahriani, 1997 ) said that participation is the active involvement in decision making as far as thing that concern them. The importance of community empowerment in tourism management is recognize by many expert tourism such as Murphy (1988),Larry Dwyer and Peter Forsby ( in Soenaryo Bambang, 2010 ) which states that, the development of tourism should be an activity that in based on society by mainstreaming that the resources and the uniqueness of the local community in the form of physical and non physical elements ( culture and tradition ) attached to the community should be the main driving element of the activities of tourism itself.

Community empowerment can also be interpreted as a process to motivate the community/individual to have the ability or empowerment so that it can determine his choice so that they prosper.

\section{RESULTS AND DISCUSSION}

As has been explained above that the Samosir is a result of the expantion of the district of Toba Samosir Which was established by Act no. 36 of 2003 and inaugurated in 2004. Samosir have territorial area that has 9 districtand 128 village. Samosir has a commodity that has potential to support the development of the region from the sectors of agriculture, mining and fisheries. More ever this district has natural and cultural resources that could be developed into a tourist attraction.

Has been described previously that the study was conducted in tree district, namely
Simanindo, Pangguruan and Onan Runggu. In the Samanindo District, the most famous tourist attraction is the village of Tomok. Tomok tourism management has been better compared to other regions. There is the sea port for ferry capable of transporting passenger, goods, and vehicle. Other tourism facilities in Tomok is the availability of tourist arrivals center providing tour guides to cater to the tourist visiting tourist sites scattered around Tomok. All these facilities are provided by local government in this case the department of tourism. Based on observations, it looks still a lack of government supervision, there is a guide that is illegal (do not wear badges), it can cause discomfort for the tourist such as fraud and other.

Historical attraction that attract many tourists in the Simanindo is stone chair hearing was the legacy of king Batak village Siallagan. Anciently court for various crimes done in this place, including the death penalty. In the Siallagan village, there are also traditional Batak houses relics of the King Siallagan. The tourism assets managed by the heirs of the King Siallagan. All the rules that existed at attraction created by the heirs.At the entrance at each attraction there is the tube of money, every traveler through the guide asked to provide additional voluntary contributions to fund the upkeep of assets such travel.

Nature tourism in sub district Simanindo is "batuhoda" beach, Traveler who come here are relatively many, mainly local traveler, although the existing facilities was minimal. Management on these place by the local community, the government has not done anything to promote tourism in this place. Other natural tourism in Simanindo is 'Tao island', is 5 minute drive from the Sangkal village. Many traveler from foreign country who visit here. The government has a lot to fix this place. Cottages, restaurant easily be found. In Simanindo precisely in Tomok can be found many small shops selling various souvenirs such as clothes, bags, carving and others, are all pattern 'Ulos' (Batak Traditional cloth). 


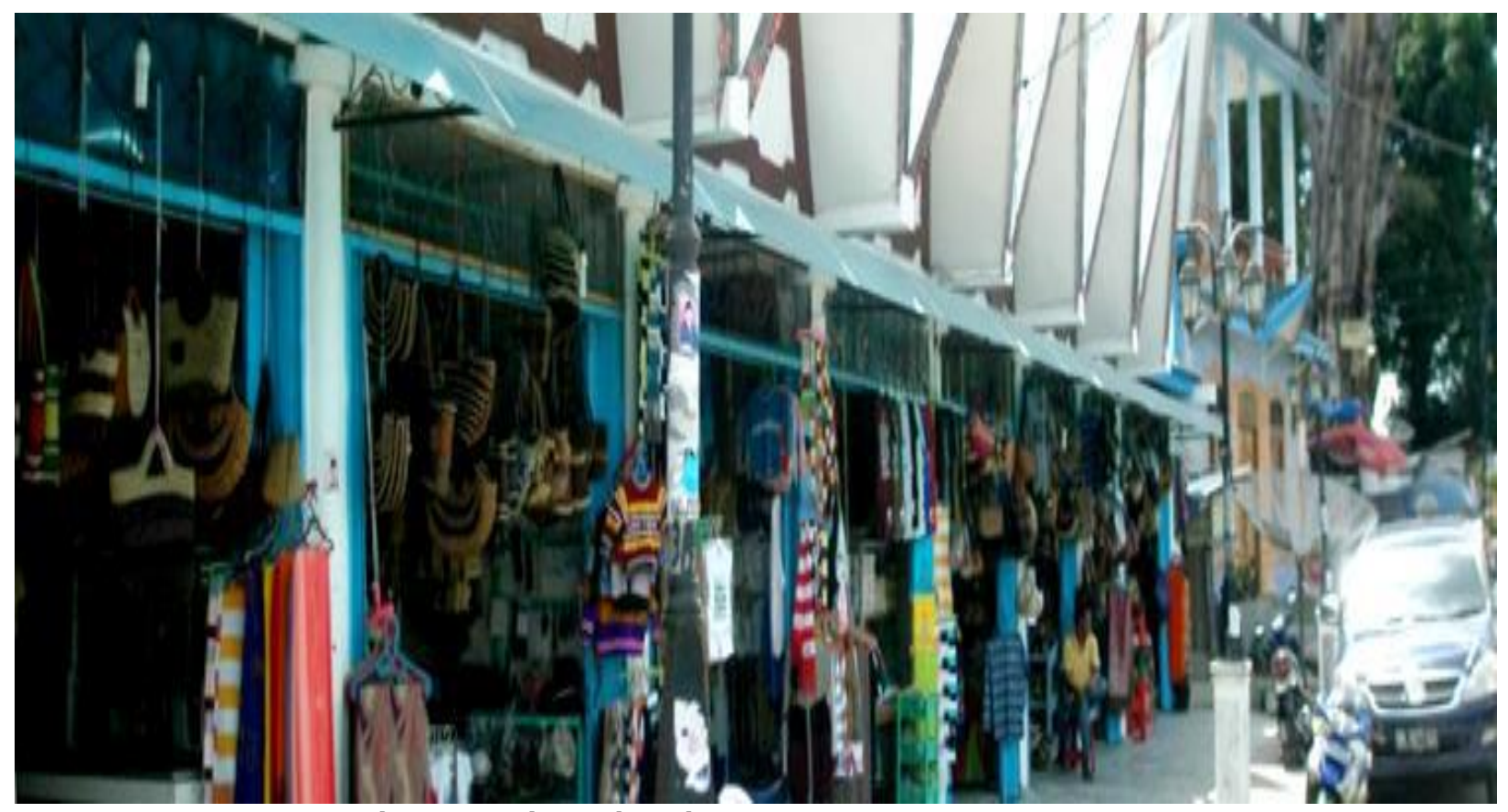

Photo 1 Traditional Market

Sub district Onan Runggu also has a great tourism potential, especially nature. One is 'Pasir Putih Sukkean beach' .This beautiful beaches have not been well managed mainly by government. Looked dirty and a lot of household waste being dumped on the beach and many people who was clothes on the beach without any restrictions. The result of interview with some local people shows that the government has not done anything and they were never consulted to develop tourism. The road

conditions is not very supportive because many are damaged.

According to several informants, cannot be the development Pasir Putih Sukkean beach cannot entirely the fault of the government, because there are people who think that their ancestors belong to the coast and only heirs who could take care of it. While they do not have the funds to develop its own without outside assistance. 


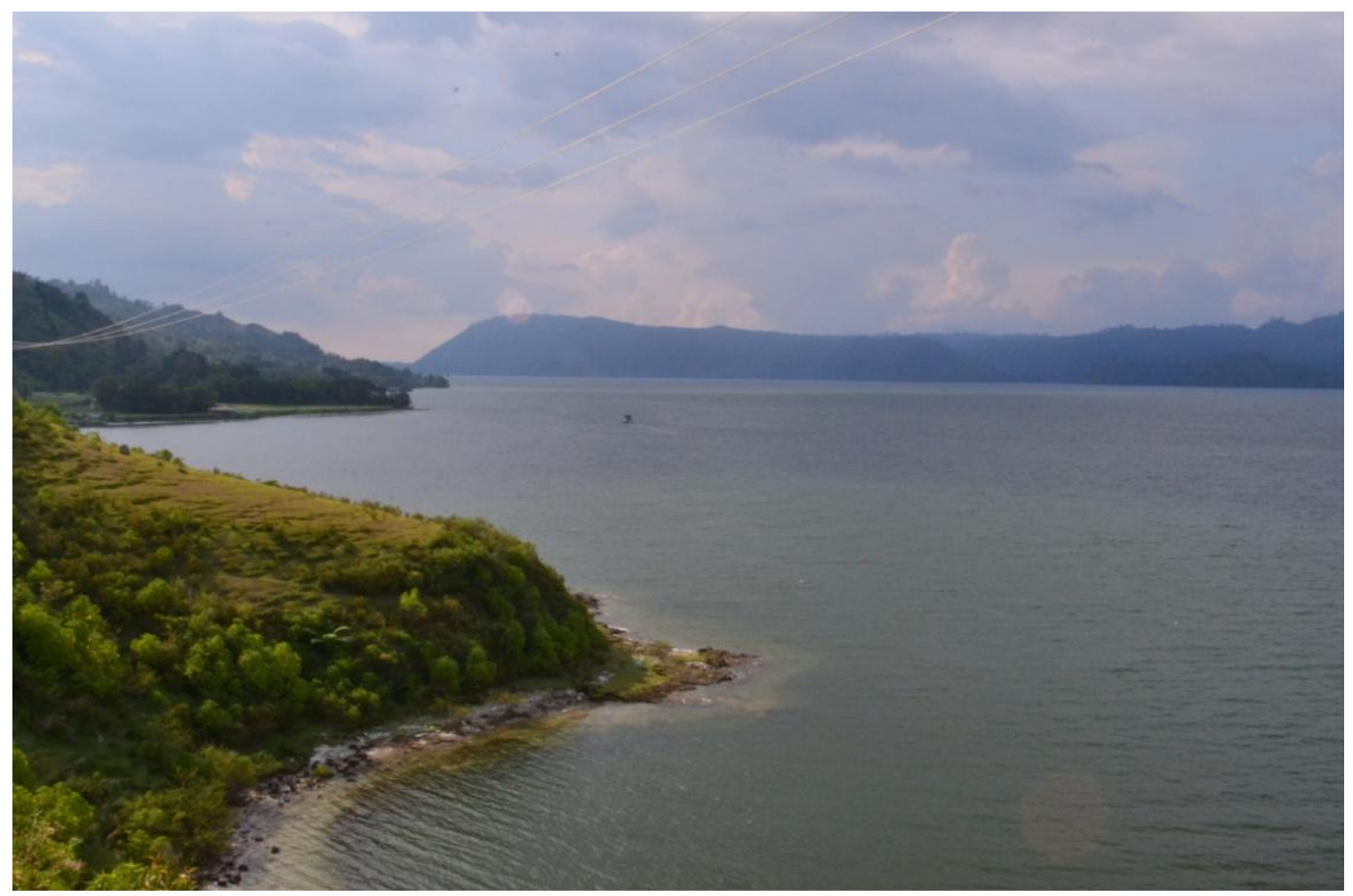

Photo 2. Pasir Putih Sakkean beach in view of the top of the Hill

Condition Pasir Putih Sakkean beach are empty of travelers and not maintain can be seen in the image below.

Sub District Pangururan also has many tourism assets, including 'Pantai Pasir Putih Parbaba'. Crowded by tourist both local and foreign especially for those who love beach activities and water sport.This place has been managed reasonably well. In this area there is also the location of hot spring contains sulfur which is believed to cure disease. There is also a museum of object of historic relics of the past Batak.

Basically the local government has made the development of tourism by making the program as follows :

1. Doing structuring and development of all the leading tourist destinations.

Based on observations and interview with informants can be in the know that the obstacles encountered in the management of tourism on the island of Samosir is that the assets of tourism that are in there are ancestral property and only heirs who may manage, for example the relic of king Batak in the form of custom home and other, managed by heirs.
2. Access and facilities are appropriate and adequate for each destination.

3. Provide an opportunity for investors to develop tourist destinations

4. Make several cultural and sporting event on a regular both national and international.

5. Increase outreach to the local community to aware of travel.

6. Culinary travel develops, agro- tourism, ecotourism and recreational tourism.

According to information from the tourism department of Samosir, programs mentioned above has been done and much yet to be done.

\section{CONCLUSION}

Several conclusions can be noted from the results of this study as follows :

1. Samosir regency is one of regencies in North Sumatera province which is rich intourism assets that have been managed well or not. 
2. Community involvement in tourism management at several places on the island of Samosir is still lack, because the program created by the government is top down, not from the input of the community.

3. The local government through the department of tourism has made programs to develop tourism,but it has not been all realized.

4. Contraints faced in the management of tourism in Samosir is considered a historical site ancestral property, so the management should only be done with the permition of the heirs. Some of them managed by heirs.

\section{REFERENCES}

Damanik, Anton and Weber, Helmut. (2006). Perencanaan Ekowisata dari Teori ke Aplikasi, Yogyakarta: Penerbit ANDI

Dennis, L. Foster. (1994). An Introduction of Travel \& Tourism. McGraw-Hill International Editions

Emanuel de Kent. (1979). Tourism Passport To Development? Unesco - World Bank Seminar on the Social and Cultural Impacts of Tourism, Washington DC.

Kentjaraningrat. (1980). Sejarah dan Teori Antropologi I, Jakarta, UI Press

Kusmayadi. (2000) .Metode Penelitian dalam bidang Kepariwisataan, Jakarta, PT. Gramedia Pustaka Utama
Marpaung Happy \& Herman Bahar. (2002). Pengantar Pariwisata, Bandung. Alfabeta

Soekadijo, R.G. (1997). Anatomi Pariwisata: Memahami Pariwisata Sebagai Sistem Linkage.

Gramedia Pustaka Utama. Jakarta.

Spillane, James, J. (1994). Pariwisata Indonesia: Siasat Ekonomi dan Rekayasa Kebudayaan. Kanisius. Yogyakarta.

SunaryoBambang. (2013). Kebijakan Pembangunan DestinasiPariwisataKonsep Dan Aplikasinya di Indonesia. Penerbit: Gava Media, Yogyakarta.

Tanudirdjo, Daud. (2003). GagasanuntukNominasi Benda Cagar Budaya Di Indonesia, Makalah Tidak Terbit.

Tanudirdjo, Daud. (2003). Pariwisata untuk semua Arah Kebijakan Pengelolaan Pariwisata Indonesia di masa mendatang, Unpublished article.

Syahriani, Tjut. (1997). Partisipasi Pedagang Kaki Lima Dalam Memelihara Kebersihan Dan Keindahan Lingkungan Di Sekitar Kampus. Research report. STIE HarapanMedan.

Syahriani, Tjut, Bangun, Sabariah. (2014). Pengelolaan Pariwisata Berbasis Budaya Di Propinsi Sumatera Utara, Laporan Akhir Penelitian Fundamental Dikti Tahun 2014.

Wahab, Saleh, dkk. (1997). Pemasaran Pariwisata. PT. Pradya Paramita. Jakarta. 